\title{
FOREIGN POLICY IMPERATIVES FOR THE DEVELOPMENT OF THE VISEGRAD GROUP AND UKRAINE
}

\author{
Vitalii Koltsov' ${ }^{1}$, Yuliia Lomzhets ${ }^{2}$
}

\begin{abstract}
The article is devoted to the analysis of the main stages of creation and development of the Visegrad Group as a regional grouping, which is successfully developing when being a member of NATO and the European Union. This kind of research is especially relevant in connection with the exacerbation of the economic crisis due to the COVID-19 pandemic. The purpose of the research is to analyze the strategic stages of creation and development of various cooperative aspects of the Visegrad countries; such a format of interaction has not lost its relevance after accession to the European Union. Analytical separation of periodization of the stages of formation, identification of problems and solutions faced by the Visegrad group's countries is important for creating a modern economic and political worldview of cooperation and indentifying the main areas of cooperation in Europe. Based on the use of documents, including protocols and declarations as a result of meetings at various levels within the Visegrad Group, the specific stages of its development and interaction with Ukraine in a wide range of components that are the essence of Euro-Atlantic integration are analyzed and identified. Specific examples illustrate that Ukraine has always been in the field of key interests of the Visegrad Four, getting effective assistance and support in various forms from it. There have been identified not only practical issues of regional cooperation and security, but also some aspects of the value and civilization dimension. The member countries of the Visegrad Group, having initiated the format of cooperation "V4 + Ukraine", took an active part in the most important processes that Ukraine went through on its way. The assumption is proved that the experience of the Visegrad countries is relevant and useful for Ukraine on the way to the realization of its Euro-Atlantic integration aspirations. Despite the difficulties within the European Union, between Ukraine and some of the signatories of the 1991 Visegrad Declaration, cooperation with Poland, the Czech Republic, Slovakia and Hungary is the most effective communication platform for intensifying a broad dialogue between Ukraine and the European Union.
\end{abstract}

Key words: the Visegrad Group, the Visegrad Four (V4), the European Union (EU), NATO, Ukraine, integration.

JEL Classification: F60, 010, 057, R19

\section{Introduction}

Scientific analysis of the history, theory and practice of cooperation of Central European countries of the "Visegrad Four" in the context of the modern European integration processes is important to develop and implement the foreign and domestic policy of Ukraine at the present stage. At the beginning of the 21st century, given the changing geopolitical situation on the European continent, the countries of Central Europe (full members of the European Union) are building a new system of international relations and accordingly delegate and continue to delegate some powers to EU supranational institutions.

In recent years, 2017-2020, the Visegrad Group countries have been criticized in the EU. Especially,
Poland and Hungary have been criticized for authoritarian and nationalist rhetoric and politics. The EU also accuses the V4 countries of violating Article 7 of theTreaty of Lisbon and the organisation's fundamental values. Slovakia has been at the center of a scandal following the assassination of investigative journalist Jan Kuciak, whose investigation has linked the mafia's ties to the country's leadership.

The 2019 summit of the Visegrad Four and Israel in Jerusalem was canceled due to Poland refused to participate (Zaxid.net, 2019).

Nevertheless, both the EU and the USA are trying to find points of understanding with the Visegrad countries, and 2019 was the example. Firstly, on February 7, 2019, Angela Merkel met with the prime

\footnotetext{
Corresponding author:

${ }^{1}$ Odessa regional branch of the fund for social protection of disabled, Ukraine.

E-mail: kolcovvm@ukr.net

ORCID: https://orcid.org/0000-0003-1261-3667

${ }^{2}$ Admiral Makarov National University of Shipbuilding, Ukraine.

E-mail:ylomzhets@gmail.com
} 
ministers of the Visegrad Four to mark the 30th anniversary of the fall of the Iron Curtain, which brought freedom to the countries. And then the US Secretary of State Mike Pompeo paid a visit to three countries of the Visegrad Group: Hungary, Slovakia and Poland (Zaxid.net, 2019).

The "European map" of the Visegrad countries is also open to Ukraine. The urgency of the issue of international relations of the Visegrad Group countries at the regional level is determined by the perspective and logic of European integration development, because an important component of their foreign policy should be intensification of relations at a new level, dynamic development of an effective regional system of international cooperation under new geopolitical conditions.

The purpose of the research is to analyze the strategic stages of development and the format of cooperation of the Visegrad Group countries before they become members of the European Union, and especially after. The tasks determine the separation of periodization and issues of the Visegrad cooperation and the presentation of the main areas of cooperation between the countries in the region.

\section{Methodology of research}

Today, no one will deny the existence of many real results of the Visegrad Four. Given that 2020 will be the 30th anniversary of the association, we consider it important to consider the history of formation and development of the Visegrad Group, the essence of the crises that have arisen and the problems of overcoming them.

In our opinion, the most valuable achievement is the presence of mutual good will and friendship between four nations. The Visegrad Group has fully ensured the stability and prosperity of the participating countries and has expanded its influence beyond the region. Cultural ties have always been in demand. The creation of the Visegrad Fund, mostly to support them, helped bring the organization closer to society, ordinary citizens. The Visegrad Group remains even more a sphere of not only high politics. In our opinion, this is manifested in the changing socio-cultural and economic level of ordinary citizens. Communications, roads, railways need to be improved, and cross-border cooperation needs to develop at an accelerated pace, creating new economic links. Cultural and other programs supported by the Visegrad Fund are another area where people can see the Visegrad Four in action.

In foreign, European, and Ukrainian literature, there are not so many analytical publications about Visegrad1, their analysis requires a separate article. Today, there are two monographs - edited by the Czech scholar Jiř́ Vykoukal (Visegrad: Possibilities and Limits of Central European Cooperation) (Vykoukal, 2003),
(Kish Yeva, 2008), (Közép-és Kelet-Európában, 2003), Vezel` B. Saakov, 2017.)

But the study of the Central European region remains relevant from the standpoint of regional foreign policy intensification and the possibility of cooperation with Ukraine and other countries of South-Eastern Europe.

The article is based mainly on documents, materials of various events, meetings, declarations and statements within the Visegrad Group and other both Ukrainian and European documents. The works of researchers who studied the development of cooperation between the Visegrad Four and Ukraine were also analyzed: Kudryachenko A. (2010), Snigyr O. (2007), Chorna N. (2017), Latenko V. (2019). Amont the researchers who have analyzed the military aspect of the interaction of the format "V4 + Ukraine", there should be mentioned Shelest, H. (2011). It is also worth mentioning the monograph of Russian scientist L. Shishelina "Visegrad Europe: where from - where to? Twenty Years on the Path of Reforms in Hungary, Poland, Slovakia and the Czech Republic", where the history of the Visegrad Group is revealed in various aspects (Shishelina, 2010).

Although the official name of the organization is the "Visegrad Group", at the same time, another title is equally used: "Visegrad Four" (V4). It should be noted that in the beginning it was the "Three", as Czechoslovakia was the only state entity in the negotiations on the formation of a new association, which took place on February 15, 1991 in Visegrad, Hungary. Poland and Czechoslovakia were represented by the Presidents Lech Wałęsa and Václav Havel, respectively, and Hungary was represented by the Prime Minister József Antall.

It is important to emphasize that the Visegrad Group was not created as an alternative to European integration, which has always been emphasized by the leaders of, firstly, three, and since 1993, by the official representatives of four countries of the Visegrad Group.

The name of the Visegrad Group refers to the historic meeting on November 1, 1335, when, in the Royal Palace of Visegrad, King Robert, the Hungarian, Czech and Polish rulers, in contrast to Austria, made strategic decisions in politics, trade, development and regulation of the northern trade route in order to strengthen trade and economic ties in particular and the role of the region in general.

As of 2019-2020, despite the events of the global crisis that befell the world economy, these countries are gradually becoming the richest in Europe. The level of per capita income, taking into account the real purchasing power of national currencies in 2019 in Poland was 33,991 USD, slightly more than in Portugal (33,665 USD). Poland outperformed Greece four years ago. We also note that according to the IMF forecasts, in 2020, the Portuguese economy will grow at a rate of 1.6 percent against 3.1 percent of the Polish economy. 
Portugal, like Poland, was overtaken by Hungary in 2019. The Czech Republic (38.8 thousand USD) approached the level of Italy (40.4 thousand USD). Authorities in Rome have not been able to overcome economic stagnation for four decades, while the Czech economy is developing quite rapidly. However, a bigger challenge for the countries of the region of South-Eastern Europe will be to reach the level of Spain (41.6 thousand USD), which in 2018 became richer than Italy (Express News, 2019).Economies in the countries of the Visegrad Four have already overtaken some Western European countries (the IMF). According to the results of the rating analysis in 2019, Russia (29.6 thousand USD) fell below Greece ( 30.2 thousand USD), and Belarus (20.6 thousand USD) had already been poorer than Mexico (20.9 thousand USD), Ukraine (9.7 thousand USD) barely surpassed Morocco (9.2 thousand USD) (Express News, 2019).

\section{Results and discussion}

\subsection{Structural periodization of the main stages of the Visegrad Group}

The history of the development of the international regional association of Central European countries the Visegrad Four - can be divided into three separate periods.

Undoubtedly, this classification is not final, but it serves as an attempt to determine, first of all, the milestones in the life of the Visegrad Group countries as an international regional association. Undoubtedly, each of these two main stages has significant features of development, so accordingly, we also note the gradation within them.

The first period, from the time of its formation in 1991 to 2004, can be defined as a period of "Association and Hope". It starts from the founding of the Visegrad Group on February 15, 1991, the accession of the Republic of Poland, the Republic of Hungary, the Czech Republic and the Slovak Republic to the European Union and including accession to NATO.

The second period has been from 2004-2014 and for the broad perspective of today's future, when the cooperation of the four countries of the Visegrad Group is already part of the European Union. The second stage can be conditionally defined as the "Time of Hopes and Disappointments", a way forward and retreat, which is mainly related to internal Ukrainian events. There are two sub-stages: 2004-2010, when during Yushchenko's presidency Ukraine was declaratively closer to Europe and began negotiations on the preparation of the Association Agreement with the EU, and 2010-2014, when under Yanukovych, an attempt to abandon the planned path and turn the entire foreign policy agenda in the opposite direction to the European - Eastern direction - took place.
The third stage has conditionally begun in 2014 and continues to this day, it can be titles as the "Time of Development and Compromises". Since the victory of the Revolution of Dignity in Ukraine, it is the period of signing and ratification of the Association Agreement and the gradual path to its implementation in practice. It should be rightly noted that during all this time, the V4 countries, which had not been members of the EU, and especially after their accession to the EU, acted as an engine of changes in Brussels' perception of Ukraine, trying to promote the importance of Ukraine's integration into Europe. Especially in this regard, the role of Poland, which has long been called "Ukraine's lawyer in Europe," differed.

Undoubtedly, this is not the final classification, it is primarily due to external and internal pragmatic circumstances, namely, the definition of the goal of the countries of international regional unification, both in 1991 (and undoubtedly the fulfillment of this goal Euro-Atlantic integration) and in 2004, as evidenced by the documents of the founding countries.

Their accession to NATO in 1999 (Slovakia was admitted to NATO only in 2004) were also important events in the Euro-Atlantic integration of Central Europe. In fact, the period 1991-2004 can be divided into several subperiods with a clear separation of the main characteristics and taking into account the differences in the nature of their cooperation, but in the context of a single constant goal: Euro-Atlantic integration of the Visegrad Group.

\subsection{Formation of the first stage of development of the Visegrad group "Association and Hopes"}

We consider it expedient to divide the period 19912004 into several sub-stages with definition of their essential characteristics.

a) 1991-1992 - "Challenge of Time" - the actual creation of the Visegrad Group, when the priority factor was security, and a strong unifying idea was the consolidation of efforts of Central European countries against a possible Soviet threat to accelerate EuroAtlantic integration. Thus, it was clear that interstate regional integration was a means, not an end, of creating association.

b) 1993-1998 - "Lost Illusions"-the collapse of illusions of the Visegrad Four countries about their rapid, almost automatic European integration of countries, as well as the problems of internal systemic transformations. In general, for other reasons, this period is distinguished as stagnation of regional Visegrad cooperation since 1993, which will actually last until 1999.

Another important event of the year was the change in the structure of the Visegrad association: the configuration of the Visegrad countries from "three" to "four" was formed in connection with the creation of two independent states: the Czech Republic and the 
Slovak Republic. It is also important to single out the sub-stage in 1994 as "Primus inter pares", the beginning of a race within the Visegrad Four on which country to be the first to join the EU. This has clearly identified at least two major fateful events of a strategic nature within the Visegrad association: this is the strengthening of Poland's ambitions for the status of regional leader, and the fact of self-isolation of the Slovak Republic. Thus, since 1994, to some extent, the first symptoms of confrontation between the members of the Visegrad association have emerged. These problems manifested themselves in organizational terms, because serious meetings began to take place only on security issues, all other issues were of protocol, format nature.

c) 1998-1999 - "Renaissance of Visegrad" - since 1998, there has been an intensification and strengthening of regional, economic cooperation, Atlantic integration of the Visegrad Four. Slovakia's invitation to cooperate within the Visegrad Group actively, which was officially made by the Prime Minister of the Czech Republic on September 11-12, 1998 at the CEFTA meeting, de facto determined the reorganization of the Visegrad Group, given the Atlantic integration of these countries.

A particularly important event of this period was the support of Slovakia's Euro-Atlantic integration by the Visegrad Group countries after the change in the domestic political situation of the Slovak Republic. It is since 1999 (Summit on May 14, 1999 in Bratislava) that we can really talk about a kind of revival of the Visegrad Group (The Visegrad Yearbook, 2003).

The security strategy has been changed, and a specified action plan has been developed in eight areas of cooperation, when the joint actions of the countries have already clearly showed dynamism and pragmatism. It is important to emphasize that the Prime Ministers of the Visegrad Four have been taking over the leading role since 1999.

f) 2000-2004. "On the threshold of the European Union" - intensification of actions of the countries of the Visegrad Four in fulfilling the conditions for their membership in the European Union; the dynamism of the systemic transformation in each of the countries of the Visegrad Group and the strengthening of cooperation between the four are particularly characteristic (the experience of systemic transformation and "catching up" European integration of Slovakia is especially instructive for Ukraine). In fact, the completion of a fundamentally important stage in the development of the Visegrad Group is considered as a fulfillment of the goal of the V4 countries in 2004, the acquisition by four countries of full Euro-Atlantic membership in the European Union and NATO.

In particular, in 2001, there have taken place the meetings of heads of the countries (January 2001); heads of government (May of the same year); Ministers of Culture (June); parliamentary delegations in the field of foreign affairs, defense and European integration
(June); Ministers of Transport (October) and many other (Selected events of V4 in 2001). In April 2001, the Visegrad Youth Conference was held in Krakow, which resulted in the signing of a declaration on the following steps (Visegrad Youth Conference, April 19, 2001):

- strengthening the role of student exchange programs between universities;

- promoting the ideas of the Visegrad association;

- sharing of kowledge about culture, economy, society, politics of the Czech Republic, the Republic of Hungary, the Republic of Poland and the Slovak Republic;

- participation in the discussion on the future of Europe; - the desire to become a bridge of cooperation between

East and West;

- striving to create a Central European identity; - support for the enlargement of the European Union.

All of the above indicates a high level of cooperation between the V4 countries in various aspects. In the following years, the regularity of such meetings and events has only increased. In 2000, the International Visegrad Fund (The official site of the Visegrad Fund, 2019) was established, which aimed to financially support cooperation between the members of the Four and other countries. In 2002, the Visegrad Scholarship Program (2019) was established to encourage educational and scientific exchange between students and researchers in the V4 countries. On April 16, 2003, the Treaty of Accession of the Visegrad Group to the European Union was signed. After that, referendums in support of the EU membership were held in all four countries (Latenko, 2019). Slovakia (92.5\%) and Hungary $(83.7 \%)$ showed the highest rates of support for accession, while in Poland and the Czech Republic the results were almost equally high (77\% each) (Shyshelina, 2010).

For the European Union, the interest in enlargement was that, firstly, the inclusion of new members should contribute to strengthening stability, security and prosperity in Europe; secondly, the domestic consumer market would grow, which would create conditions for greater competitiveness of the European companies in the world market; thirdly, by gaining wider borders, the EU has become an even more powerful player in the international arena (Shyshelina, 2010).

\subsection{Developments in the second stage of "Hopes and Disappointments"}

The second stage can be dated 2004-2014 as a time of hopes and disappointments, the way forward and retreat, which is mainly related to domestic events. There are two sub-stages: 2004-2010, when during Yushchenko's presidency Ukraine was declaratively closer to Europe and began negotiations on the preparation of the Association Agreement with the EU, and 2010-2014, when under Yanukovych, an attempt to abandon the planned path and turn the 
entire foreign policy agenda in the opposite direction to the European - Eastern direction - took place (Preskonferentsiya u Kyievi, 2009).

The enlargement of the European Union on May 1, 2004 was the biggest in its history, with 10 countries joining at the same time. There are members of the Visegrad Four among them. Certainly, this structure did not enter the EU institutionally, but received a new impetus for its activities in the new conditions. Despite the high results in national referendums, significant hopes and expectations, the process of "survival" of new members was not easy. The difference in economic development, the duration of the experience of democratic state-building in the "old" and "new" members, and the peculiarities of the European Union itself as a structure were noticeable. Despite the equality of rights between all participants in the representation in the European institutions and the alternate sixmonth presidency, the EU has historically developed its own forms of interaction and informal authority. At that time, the relations in the Berlin-Paris-London triangle largely determined the agenda of the whole community. Given the ambition of the newly admitted countries as independent players in the European space, a certain tension and problems in cooperation could not be avoided. However, the experience of overcoming contradictions and reaching compromises in the course of heated discussions ultimately made the EU, as an institution, stronger (Zub, 2018).

On May 12, 2004, a summit of the Heads of Governments of the Visegrad Four countries took place in the Czech city of Kroměříž, which resulted in signing the declaration. In the document, the parties stated the achievement of the key goals set out in the 1991 Visegrad Declaration, and also stated their determination to continue the development of cooperation between the v4 countries as members of the EU and NATO (Declaration of Prime Ministers 12.05.2004).

During 2005-2009, further meetings of Ukrainian authorities with representatives of the Visegrad Group took place. The subject of discussion was Ukraine's integration aspirations towards the EU and NATO. The countries of the Four, especially Poland, have taken on the role of active promoters of Ukraine's involvement in the European context. However, it became increasingly clear that the Ukrainian side was not inclined to radical reforms, but instead limited itself to declarative statements, which created a contrast between the form and content of the "V4 + Ukraine" format. In addition, the Visegrad countries were forced to take into account the conservative position of the "old" EU members, especially France and Germany, on the issue of Ukraine's Euro-Atlantic aspirations.

It is worth mentioning the events of the Bucharest Summit on April 2-4, 2008, where the positions of these countries hindered the submission to Ukraine of the Action Plan for NATO membership (Bucharest Summit,
April 3, 2008). This is despite the consolidated position of the Ukrainian authorities at the time, as evidenced by a joint letter signed by the President Viktor Yushchenko, Prime Minister Yuliia Tymoshenko and Parliament Speaker Arsenii Yatseniuk, asking for a MAP to Ukraine at the summit. This issue was actively promoted by the V4 countries, which were also members of NATO. However, France and Germany were able to block this decision, not least under the influence of the Russian factor. Among the new EU members, members of the former socialist camp (including the Visegrad Group) and the Baltic countries, there has always been a more restrained and critical attitude towards the Russian Federation, in contrast to the Franco-German alliance, where the business and economic interests of their representatives often became hindering the adoption of more specific wording in statements and more decisive action when it was absolutely necessary (Shelest, 2011).

The Visegrad Group countries took an active part in the development of the EU's Eastern Partnership policy, which was launched in Prague on May 7, 2009. The idea of the Eastern Partnership was presented by Poland at a meeting of the EU Council in May 2008. Among the six countries to which this form of cooperation was to extend, the leading place belonged to Ukraine (Ofitsiynyi sayt programy YeEs "Shidne partnerstvo", 2009). The basis of this format was the initiative of the then-Minister of Foreign Affairs of Poland Radosław Sikorski. The aim was to deepen the integration between the European Union and Ukraine, in particular in the four main areas cited by N. Chorna in her work: “1) democracy, good governance and stability, including justice, freedom and security; 2) economic integration and approximation to the EU policy; 3) energy security; 4) economic and social development" (Chorna, 2017).

\subsection{Prospects for cooperation between the countries of the Visegrad Four and Ukraine}

In a declarative manner, during 2010-2013, the Ukrainian authorities demonstrated their readiness to continue moving towards rapprochement with the European Union, which was reflected in the further development and preparation of the Association Agreement with the EU, including its economic part related to the free trade area. In addition, Ukraine has continued to participate in the Eastern Partnership initiative. The Visegrad Four countries played a key role as a communicator between official Kyiv and Brussels. The V4 + Ukraine format continued to be active as an intermediate platform in more global negotiations between Ukraine and the EU. There were also other events where the Ukrainian side was also invited. For example, on February 15, 2011, in addition to the Heads of Governments of Austria and Germany, the Ukrainian delegation headed by the Prime Minister Mykola Azarov was invited to the extended summit 
of the Prime Ministers of the V4 countries on the occasion of the 20th anniversary of the Visegrad Group (February 15, 2011).

On September 25, 2012, at a meeting of the Foreign Ministers of the Visegrad Four and the Benelux countries in New York, a Joint Statement on Ukraine was adopted, where participants called on the Ukrainian government to respect basic human rights in the country (Joint Statement by the Visegrad Group, September 25, 2012). Noting Ukraine's European aspirations, the statement pointed to regressive trends in the general state of democracy. Ministers noted the deteriorating situation in the areas of rule of law, human rights, freedom of the media and more. It was emphasized that the lack of progress in these areas could be a serious obstacle to Ukraine's pro-European path, including the signing of the Association Agreement with the EU.

This was the second stage in the development of relations between Ukraine and the Visegrad Group. After the Revolution of Dignity, the annexation of Crimea and the military invasion of the Russian Federation on Ukrainian territory, the third stage of the "V4 + Ukraine" format began, which opened a fundamentally new page in bilateral communication. In 2014 alone, 8 different meetings dedicated to the events in Ukraine took place within the framework of the Visegrad Four. In the midst of the active confrontation between the President Viktor Yanukovych's regime and civil society on the Maidan, on January 29, 2014, the Joint Statement of the Prime Ministers of the countries of the Visegrad Group on Ukraine appeared, where participants expressed the firm belief that the use of force could not help resolve political conflicts.

In general, it can be noted that the Visegrad Group, both the institution and each of its components, did not stay away from any significant and key events that took place in Ukraine. Thus, we can recall the meeting of Foreign Ministers of the countries of V4 in Budapest on February 24, 2014, where in the final statement the parties expressed their condolences to all those killed on the Maidan and welcomed the steps towards a peaceful solution to the conflict (Joint Statement of January 29, 2014). On March 4, 2014, a statement was issued by the Statement of the Prime Ministers of the Visegrad countries regarding Ukraine, stating the inadmissibility of violating the territorial integrity and internationally recognized Ukrainian borders (Statement of March 5, 2014). A day later, on March 5, the EU High Representative for Foreign Affairs and Security Policy C. Ashton and the European Commissioner for Neighbourhood and Enlargement Š. Füle received a joint letter signed by the foreign ministers of all members of the Visegrad Four with a request to support Ukraine with real steps in its aspiration to return to the European integration path of its development (Joint V4 Foreign Ministers' March 4, 2014).
In general, it is a fair assumption to say that since 2014, the countries of the Visegrad Group have been actively helping Ukraine in its aspirations to the EU and NATO. This is noticeable both at the level of statements of various kinds and in specific actions, including the final signing and ratification of the Association Agreement between Ukraine and the European Union and as a consequence - providing Ukrainian citizens with visa-free travel within the EU. A separate block is issues related to the Russian military invasion of Ukrainian territory. Here, the Visegrad Group countries have an unequivocal position in support of the territorial integrity and sovereignty of Ukraine (Text Ugody, 2014).

In connection with the above-mentioned events, in recent years, cooperation in the military field within the V4 + Ukraine format has become increasingly important. Since 2002, regular meetings of the Ministers of Defense of the Visegrad Group have been held to discuss the most pressing issues of defense policy. Since 2005, representatives of the Ukrainian side have often been invited to such meetings (Kaplynskiy, 2009).

In 2019, the regulatory framework, which enshrines the strategic foundations of Ukraine's foreign and security policy, noted some changes. Some of these changes were the result of a previously defined policy, which was formalized in 2019, but at the same time had a certain political twist. The other part was due to the change of the presidential and governmental team after the election, which required a new definition of the system of foreign policy coordinates and tasks. The main event of the year on the strategic consolidation of the state's foreign policy was the adoption by the Verkhovna Rada of the Law of Ukraine "On Amendments to the Constitution of Ukraine (Regarding the Strategic Course of the State for Acquiring Full-Fledged Membership of Ukraine in the European Union and in the North Atlantic Treaty Organization)" in February. The initiative of the President P. Poroshenko to amend the Constitution of Ukraine was proposed in mid-2018. The law provides for amendments to a number of articles of the Constitution, which define the powers of the Verkhovna Rada (Art. 85 of the CU), the President of Ukraine (Art. 102), as well as the CMU (Art. 116. In particular, the parliament is authorized to implement the strategic course for Ukraine's full membership in the EU and NATO, and the government must ensure the implementation of this course. At the same time, this bill and the changes it introduced had a rather political effect (both domestic and in communication with international partners). Cooperation with the EU and NATO has continued, based on agreements, action plans and roadmaps that have been in place for several years. The updated Annual National Program Ukraine-NATO, which changed the methodology of 
development to measurement indicators, the results based management has become an important internal complement to external commitments.

V. Zelenskyi's team declared "economization of foreign policy" a major foreign policy priority, which, in addition to political statements, resulted in a corresponding redistribution of government powers and the assignment of relevant tasks to the Foreign Ministry in O. Honcharuk's government program. During the autumn, the Cabinet of Ministers audited the current opportunities for intensification of foreign economic activity. The intentions to make changes to the Export Strategy of Ukraine adopted at the end of 2017 have been announced. In public statements, the President of Ukraine has repeatedly promised to give priority to the protection of foreign business and investors in Ukraine.

\section{Conclusions}

The Visegrad Group proved to be a format of regional cooperation, due to the constructive cooperation in which Poland, Hungary, the Czech Republic and Slovakia were able to achieve a number of important tasks, first of all, to join NATO and the EU. Despite the existing forecasts, with the accession to Euro-Atlantic and European structures, the Visegrad Four did not cease its activities, but on the contrary, received new impetus to its continuation. The countries have joined forces to adapt to the new conditions, as well as to develop a common course within the Union institutions. The latest geopolitical challenges that have recently emerged in Europe are forcing the Visegrad participants to work together to find an adequate answer to them.

Undoubtedly, a qualitatively new period of Visegrad's development began in 2004, the accession to the EU as a test of the viability of the system of multilateral international regional project in a new format in the new geopolitical situation. A characteristic, if not the main feature of this period will be the coordination of the interests of the Visegrad Four not only among themselves in order to achieve certain goals, but also in a new format of relations with the EU and separately with EU member states.

We consider it too simplistic to understand the essence of the Visegrad association only as a consolidation of the efforts of the countries of Central Europe for the purpose of "returning to Europe" through Euro-Atlantic integration. That is, the "European map" was priorityoriented, but not comprehensive. This is a much more complex and multifaceted problem than is thinkable. After all, the accession of the Visegrad countries (and this, in our deep conviction, are the countries of Central Europe) in 1999 and 2004, to NATO and the European Union, geopolitically changes the status of the Central European region, transforms bilateral and multilateral relations Europe - full members of the EU with Ukraine.
Moreover, the system of relations within the Visegrad Four is changing, as well as with other member states of the European Community.

The complex mosaic of actions of the Visegrad countries was determined for a certain period of time by choosing between strengthening the interregional integration of the Visegrad countries and creating a strong subregional structure, or using it as a forum to protect and promote their own or common interests.

As a result of radical socio-political transformations in the late 80 s - early 90 s of the 20th century in Central Europe, there was a radical change in the domestic political system and foreign policy of these countries and the radical transformation of international relations as a global level.

Firstly, the collapse of the bipolar system of international relations has significantly changed the status of the Central European region and each country.

Secondly, all the countries of Central Europe were at the beginning of the period of systemic socio-economic transformations, priority in this context were foreign economic relations aimed at the West. The foreign policy security priorities were somewhat different in the countries of the Three and then the Four. However, during 1991-2000, in all four Visegrad countries, the Euro-Atlantic dimension became the main focus in building and strengthening the European security system in the region.

Thirdly, the "overcoming" of the geopolitical vacuum in the Central European region against the background of general instability, Central European countries saw in joining strong international and regional structures of economic and security nature, in particular, the Euro-Atlantic course and joining the European Community were given priority. The foreign policy strategies of Poland, Hungary and Czechoslovakia were clearly oriented towards the West. That is, the actual formation of the Visegrad association did not serve as any alternative to their earliest accession to the EU and NATO.

It should also be noted that the Visegrad Group, as a regional format of cooperation, has proved its effectiveness and does not lose relevance even after the official achievement of the key aspiration for which this structure was formed: Poland, Czech Republic, Slovakia and Hungary to join the North Atlantic Alliance and the European Union. The experience of almost 15 years in the EU and 20 years in NATO has shown that the Visegrad Four has become an important communication platform, which often serves as a liaison between those countries that either aim to integrate into the structure or also seek to build mutually beneficial good neighborly relations with its member countries.

The V4 + Ukraine format has undoubtedly become the key and most effective among similar projects in Eastern Europe. The Visegrad Four has always helped 
our country to realize its Euro-Atlantic aspirations, even in spite of certain difficulties that have arisen in recent years in bilateral relations between certain V4 countries and Ukraine. And although it is not possible to simply use the patterns of the Visegrad experience, given the specifics of Ukraine, nevertheless, many aspects and reforms implemented by the V4 countries are an example for Ukraine. The experience of not only what and how to do to become a member of the EU and NATO, but also what will happen after the accession, as, already being a full member of a union, in search of a common compromise, is important to defend the national interests of the country.
As of the end of 2019, positive results were achieved in the direction of Ukraine's integration with the EU both in the political and security dimension and in financial and economic cooperation. An important document of Ukraine's political support was the Joint Declaration following the Ukraine-EU Summit (July). The EU's political leadership reaffirmed its support for Ukraine's territorial integrity and sovereignty, the progress of reforms, and the European integration course. It is important that the reset of the EU institutions as a result of the elections to the European Parliament in May 2019 did not lead to a change in the position of official Brussels in support of Ukraine.

\section{References:}

A 1991-es Visegrádi Nyilatkozat a Cseh és Szlovák Szövetségi Köztársaság, a Lengyel Köztársaság és a Magyar Köztársaság együttmüködéséről az európai integráció útján. Kelt Visegrádon, 1991. február 15-én 3 eredeti példányban, cseh, lengyel és magyar nyelven.

Boros Ferenc (2003). A Visegrádi Együttműködés és perspektívája. Külügyi Szemle, № 2, pp. 79-81.

Bucharest Summit (03.04.2008). Bucharest Summit Declaration Issued by the Heads of State and Government participating in the meeting of the North Atlantic Council in Bucharest on 3 April 2008. Available at: http://www.summitbucharest.ro/en/doc_201.html

Chorna, N. (2017). Krayiny Vyshegradskoyi grupy ta Ukrayina: dosvid ta perspektyvy spivrobitnytstva. Available at: http://chtyvo.org.ua/authors/Chorna_Nataliia/Krainy_Vyshehradskoi_hrupy_ta_Ukraina_dosvid_ ta_perspektyvy_spivrobitnytstva/

Čarnogursky, J. (2006). Visegrad Today and Tomorrow. The Visegrad Group - A Central European Constellation. Bratislava.

Declaration of Prime Ministers (12.05.2004). Declaration of Prime Ministers of the Czech Republic, the Republic of Hungary, the Republic of Poland and the Slovak Republic on cooperation of the Visegrad Group countries after their accession to the European Union. Available at: http://www.visegradgroup.eu/2004/declaration-of-prime

Dientsbier J. Visegrád 1999. Mezinárodní politika, roč. XXIII, č. 2, s. 4-7; Nemzeti identitás és külpolitika.

Express news (2019). Available at: https://espreso.tv/news/2020/02/25/ekonomiky_u_krayinakh_ vyshegradskoyi_chetvirky_vzhe_obignaly_deyaki_derzhavy_zakhidnoyi_yevropy_mvf

Extended summit of the V4 (February 15, 2011). Prime Ministers with Prime Ministers of Austria, Germany and Ukraine on the occasion of the 20th anniversary of the Visegrad Group, Bratislava. Available at: http://www.visegradgroup.eu/calendar/2011

Hamberger Judit (2004). A visegrádi együttmüködés cseh szemmel. Klió. № 2-3.

Jeszenszky, G. (1998). A „visegrádi gondolat, és az euró-atlanti integráció. Magyar Szemle. № 7/8.

Jeszenszky Géza (1994). Külügyminiszter nyílatkozata Magyarországnak az Európai Unióhoz való csatlakozása kérelmének átnyújtása alkalmával. Magyar Külpolitikai Évkönyv. A Külügyminisztérium Dokumentációs Főosztálya. Bp.: Vadas.

Joint Statement by the Visegrad Group and the Benelux countries on the situation in Ukraine (September 25, 2012). Available at: http://www.visegradgroup.eu/calendar/2012/joint-statement-by-the

Joint Statement of the Prime Ministers of the Visegrad Group Countries on Ukraine (January 29, 2014). Available at: http://www.visegradgroup.eu/calendar/joint-statement-of-the

Joint Statement of V4 Foreign Ministers on Ukraine (February 24, 2014). Available at: http://www.visegradgroup.eu/ joint-statement-of-v4

Joint V4 Foreign Ministers' Letter on Ukraine to Ashton and Füle [PDF] (March 4, 2014). Available at: http://www.visegradgroup.eu/calendar/2014

Krejči, O. (2005). Geopolitics of the Central European Region: the view from Prague and Bratislava. Br.: Veda, 493 p. Közép-és Kelet-Európában (2003). Szerkesztette Kiss J. László. Budapest: Teleki László Alapitvány, 396 p.

Kish Yeva (2008). Central Europe in the modern system of Euroregional integration. Uzhhorod: Lira.

Kudryachenko, A. (2010). Ukrayina i Vyshegradska chetvirka: stan ta perspectyvy spivpratsi. Ukrayina i Vyshegradska chetvirka na shlyahy do vzayemovygidnyh vidnosyn: materialy mizhnar. konferentsiyi «Ukrayina i Vyshegradska chetvirka na shlyahy do vzayemovygidnyh vidnosyn $\gg 13-14$ travnya 2010. Research Center of the Slovak Foreign Policy Association Bratyslava, pp. 37-53.

Latenko, V. (2019). Visegrad Group: history of creation and experience of cooperation with ukraine in the context of european integration. Yevropeiski istorychni studii. № 13. Available at: https://drive.google.com/file/ d/1OgmBlxsP9XVHBi5CCAc_t5Dc97cJAQkz/view 
Ofitsiynyi sayt programy YeEs «Shidne partnerstvo» (2009). Available at: http://www.easternpartnership.org/ Selected events of V4 in 2001. Available at: http://www.visegradgroup.eu/calendar/2001

Statement of the Prime Ministers of the Visegrad Countries on Ukraine (March 5, 2014). Available at: http://www.visegradgroup.eu/calendar/2014/statement-of-the-prime

Shelest, H. (2011). «Vyshegradska chetvirka»: u poshukah subregionalnoyi bezpeky? Available at: www.od.niss.gov.ua/articles/449

Shyshelina, L. N. (2010). Vyshegradskaya Yevropa: otkuda i kuda? Dva desyatiletiya po puti reform v Vengriyi, Polshe, Slovakiyi i Chehiyi. Moskwa: Ves Mir.

Snigyr, O. (2007). Spivpratsia Ukrayiny ta novyh derzhav chleniv YeEs: perspectyvni napryamy. Analitychni zapysky schodo problem i podiy syspilnogo rozvytku. Naukova diyalnist. Analitychni materialy NISD. Available at: http://www.niss. gov.ua/Monitor/Desember/10.htm

Text Ugody (2014). Pro asotsiatsiyu mizh Ukrayinoyu ta Yevropeyskym Soyuzom (2014). Available at: https:/ /www.kmu.gov.ua/ua/diyalnist/yevropejska-integraciya/ugoda-pro-asociacyu

The Visegrad Yearbook. 2003. Central European Student Partnership Organisation, Budapest. 482 p.

The official site of Visegrad Fund. Available at: https://www.visegradfund.org/

Visegrad Youth Conference (April 29, 2001). Available at: http://www.visegradgroup.eu/2001/visegrad-youth

Visegrad Declaration 1991. Retrieved January 15, 2019. Available at: http://www.visegradgroup.eu/documents/ visegrad-declarations/visegrad-declaration-110412

Visegrad Scholarship Program. Retrieved January 20, 2019. Available at: https://www.visegradfund.org/apply/ mobilities/visegrad-scholarship/\#rules

Visegrad Youth Conference (April 29, 2001). Available at: http://www.visegradgroup.eu/2001/visegrad-youth

Pres-konferentsiya u Kyyevi 2 kvitnya 2009 r. Krayiny Vyshegradskoyi chetvirky - u NATO. A Ukrayina? Available at: www.dif.org.ua/ua/events/bfgb

Vykoukal, J. (2003). Visegrád: možnosti a meze středoevropské spolupráce, Praha, Dokořán, s. 405.

Vezel' , B., \& Saakov, V. (2017). Samit YeS - najvazhlyvishi temy zustrichi na Mal’ ti. Deutsche Welle. Available at: http://www.dw. com/uk/\%D

Zaxid.net, 2019. Available at: https: / / zaxid.net/news/

Zub, S. (2018). The main factors of internal and external interaction of the Visegrad Group countries. Geopolitics of Ukraine: history and modernity, vol. 1(20), pp. 231-249. 